\title{
EXPLORING SELF-MOTIVATION IN CONTRIBUTING STUDENT PERSISTENCE IN THE INDONESIA OPEN UNIVERSITY
}

\author{
Muhammad Husni Arifin \\ Indonesia Open University (Indonesia)
}

\begin{abstract}
s
The high number of non-enrolment students has affected retention rates in the Indonesia Open University. This study was aimed to explore contribution of self-motivation on student persistence in the Indonesia Open University by employing mixed methods approach. Student progress in this study refers to continuation of enrolment within four consecutive semesters. The design of sequential explanatory study was opted by obtaining the quantitative findings from surveying 153 students and then was followed by semi-structured interview with 13 purposefully selected participants. In the quantitative phase, intrinsic and extrinsic motivation had important contribution to student persistence. Meanwhile, the qualitative phase demonstrated that intrinsic and extrinsic motivation did not stand in conflict each other but co-exist together in influencing student persistence in the Open University context. This finding refined previous theory of self-motivation that extrinsic motivation could undermine learner's intrinsic motivation. In this study, quantitative and qualitative findings are integrated and interpreted by referring to previous empirical studies.
\end{abstract}

Keywords: Self-motivation, Student Persistence, Open University.

\section{INTRODUCTION}

The increasing of student population in Open and Distance Learning in recent years has not kept up with the increasing of student persistence rates in Open and Distance Learning (ODL). Several studies noted that student persistence is as low as ten percent and lower than in face-to-face programmes (Carr, 2000; Diaz \& Cartnal, 2006; Simpson, 2003). The low persistence rates, of course, will lead to negative impacts for the students, institutions, and society. The incompletion or failure in a distance course may negative effects on student's motivation, self-esteem, and self-confidence. Furthermore, the withdrawal of a distance course may also influence the institution's performance, particularly as a sign of inefficiency (Poellhuber, Chomienne, \& Karsenti, 2008).

Persistence rates also remain a big problem for Indonesia Open University (Universitas Terbuka). Prior empirical studies have noted that Indonesia Open University having a low rate of completion and a low level of achievement (Belawati, 1998; Kadarko, 2003; Ratnaningsih et.al., 2008). Currently, Indonesia Open University has enrolled about 299,317 students, spread out in different parts of the country and some overseas locations. Over $90 \%$ of these students are working adults (Universitas Terbuka, 2016). Moreover, since its foundation in 1984, Universitas Terbuka has enrolled over 1.4 million students and has produced more than 700,000 alumni, working in various professional fields (Universitas Terbuka, 2012). This data revealed that the Indonesia Open University has high enrolment, but low completion rates.

The relationship between motivation and student persistence has been identified by prior empirical studies. A review on prior studies of student persistence in ODL conducted by Lee \& Choi (2011) has identified a pivotal relationship between student's motivation and student retention. In the Open University contexts, a qualitative study undertaken by Castles (2004) at the UK Open University revealed that level of learning motivation has been seen as an important factor in influencing student persistence. Furthermore, Lee \& Choi (2012) showed the significant relationship between internal academic locus of control and student persistence at the Korean National Open University.

However, student motivation has been noted to be a multidimensional and complex phenomenon as students of ODL are motivated in different ways and need to look into multiple perspectives in explaining motivation, such as learning characteristics, cultural background, and learning environment 
design (Hartnett, St. George, \& Dron, 2011). Therefore, it is important to know the relationship between motivation and student persistence in the specific context of Indonesia Open University. Moreover, the significance of this study relates to the paucity of empirical studies on student motivation and student persistence at the Indonesia Open University.

\section{LEARNING MOTIVATION}

Most researchers in distance education would agree that motivation has a significant role in determining student achievement and persistence. Furthermore, they argue that motivation is not only a necessary condition for success but is also a sufficient one. A motivated learners will overcome barriers of situation and time, find ways of developing appropriate skills and be able to deal with the stress of study with very little extra external support (Simpson, 2008).

Lee \& Choi (2011) revealed that psychological attributes were the most frequently researched category of factors in their reviewed studies of persistence in distance education (20\%). Psychological attributes encompass various aspects of students' attitudes towards learning in general, toward particular courses, and toward their interaction with their instructor and other students. The studies on students' psychological attributes explained that students possessing an internal locus of control and/or higher levels of self-motivation, self-efficacy, satisfaction with courses, and confidence in their computer skills were more likely to complete online courses (Chyung, 2001; Ivankova \& Stick, 2007; Osborn, 2001).

Ivankova \& Stick (2007) delineated in their mixed methods study that self-motivation was a quantitatively significant predictor on student persistence in the distance education programme. This finding was supported by case study analysis that motivation was a strong factor for successful students. Self-motivation was measured by indicators of love for learning, personal challenge, a lifelong dream, and experiencing the new learning format. Similarly, Osborn (2001) found that a student's motivation had significant contribution on a students' decision to drop out. In this study, motivation was measured by questions about each student's attitude towards their learning goals, homework, and interaction with peers.

Morris et al. (2005) examined the predictors of retention in online general education courses at the University System of Georgia. Discriminant analysis revealed that locus of control significantly predicted student attrition with $74.5 \%$ accuracy (i.e. Locus of control was measured by Rotter's (1966) internal-external locus of control scale or I-E scale). Locus of control indicates the difference between internal and external motivation. Individuals with internal motivation believe that events occurred due to their own interest, needs, and behaviour. Those with external motivation believe that events are decided by environmental factors such as rewards and punishment. Similarly, Parker (2003; 1999) reported also that a student's internal locus of control was found to be a positive indicator of persistence in online courses.

On the other hand, Holder (2007) explained that the completing students in online courses tend to score higher self-efficacy, emotional support, and time and study management. The level of perceived emotional support accounted for a large portion of the environmental scale difference between persisters and non-persisters. Having the experience of a supportive group of friends and family and the comfort of knowing that they are not alone in this learning process was a significant function related to students' persistence. Those who also had high self-efficacy for learning and performance had higher expectations to do well in their programme and a strong sense of their own personal ability to succeed in their new learning environment. An additional key factor of successful students related to their time and study management. The persisters practised good study habits, kept up with the weekly reading and assignments, and managed their time and activities to a greater degree than did the non-persisters.

Poellhuber, et al. (2008) reported in their mixed methods study of the impact of peer interaction and collaborative learning on student self-efficacy beliefs and persistence in a distance education context. The finding of the quasi-experimental study revealed that students' motivation to persist in the online courses was not influenced by peer interaction. Meanwhile, the qualitative study delineated that collaborative learning had important contribution in developing self-efficacy and increasing persistence. 


\subsection{Learning Motivation in Self-Determination Theory}

One of the most referenced, researched, and validated theory for understanding educational motivation in distance education is self-determination theory (SDT) (Chen \& Jang, 2010; Guifrida, 2006; Simpson, 2008). According to SDT (Ryan \& Deci, 2000a, p. 54), a motivated people refers to a person who is energised to do something toward a goal. In the context of educational motivation, SDT elucidates that people or students are motivated to learn by one of two motivational orientations: (a) intrinsic motivation which refers to doing something because it is inherently interesting or enjoyable, or learning because one finds the content interesting; or (b) extrinsic motivation which refers to doing something because it leads to a separable outcome, or learning as a means to an end (Deci, Vallerand, Pelletier, \& Ryan, 1991; Guifrida, 2006; Ryan \& Deci, 2000a, 2000b; Vallerand \& Bissonnette, 1992). Moreover, SDT addresses the state of lacking intrinsic or extrinsic motivation which is defined as 'amotivation' (Ryan \& Deci, 2000, p. 61). Amotivation results from not valuing an activity, not feeling competent to do it, or not believing it will yield a desired outcome. Amotivation is found to be associated with learned helplessness and poor academic performance. However, SDT is central to human's intrinsic need to learn and develop. Therefore, the most meaningful and successful learning occurs when students are motivated intrinsically (Guifrida, 2006; Niemiec \& Ryan, 2009; Ryan \& Deci, 2000a, 2000b; Sungur \& Senler, 2010).

\subsubsection{Intrinsic learning motivation}

Intrinsically motivated learners are those who learn something for the pleasure and satisfaction. In other words, intrinsic motivation refers to doing an activity for the inherent satisfaction of the activity itself. Therefore, an intrinsically motivated student goes to class because he or she finds it interesting and satisfying to learn more about certain subjects rather than controlled by some external reasons, such as good grades, rewards, or avoidance of negative consequences (Deci et al., 1991; Ryan \& Deci, 2000a, 2000b; Sungur \& Senler, 2010; Vallerand et al., 1992; Vallerand \& Bissonnette, 1992).

According to SDT (Ryan \& Deci, 2000a, 2000b), intrinsic motivation in learning focuses on three psychological needs: the innate needs for autonomy, competence and relatedness. The first focus is the need for autonomy. The autonomous students are those who choose, in their own, to become engaged in learning because the subject and activities are closely aligned to students' interest, curiosity, and values (Guiffrida, 2006). For example, students are autonomous when they self-endorse in respect of allocating time and energy to their studies (Niemiec \& Ryan, 2009). The second need is competence or the need to be effective in interactions with the environment (Guiffrida, 2006). For example, students are competent when the feel able to meet the challenges of their assignments. Importantly, satisfaction of both autonomy and competent need is essential to maintain intrinsic motivation for learning (Niemiec \& Ryan, 2009). The third requirement is relatedness or the need to establish close, secure relationship with others (Guiffrida, 2006). The primary reason people are likely to be willing to behave accordingly is that they are valued by significant others to whom they feel (or would like to feel) connected, whether that be a family, a peer group, or a society (Ryan \& Deci, $2000 \mathrm{a}, 2000 \mathrm{~b})$. In the classroom, relatedness is deeply associated with a student feeling that the teacher genuinely likes, respects, and values him or her. Students who report such relatedness are more likely to exhibit identified and integrated regulation for the arduous task involved in learning, whereas those who feel disconnected or rejected by teachers are more likely to move away from internalisation and thus respond to external contingencies and controls (Niemiec \& Ryan, 2009).

\subsubsection{Extrinsic learning motivation}

Extrinsic motivation refers to a wide variety of behaviours performed to obtain some outcome beyond those inherent in the activity itself (Niemiec \& Ryan, 2009; Ryan \& Deci, 2000a, 2000b; Vallerand \& Bissonnette, 1992). According to SDT, there are four types of extrinsic motivation which can be ordered along a self-determination continuum, and the process of internalisation is important for transformation of extrinsically motivated behaviours into self-determined behaviours. Internalisation involves assimilation and reconstitution of formerly external regulatory processes into internal regulatory processes (Sungur \& Senler, 2010). The four types of extrinsic motivation are (a) external regulation, (b) introjected regulation, (c) identified regulation, and (d) integrated regulation (Niemiec \& Ryan, 2009; Ryan \& Deci, 2000a, 2000b; Vallerand \& Bissonnette, 1992).

External regulation is the least autonomous form of intrinsic motivation. Such behaviours occur to satisfying an external demand or obtaining an external rewards or constraints (Ryan \& Deci, 2000a, 2000b; Vallerand \& Bissonnette, 1992). For example, a student might study for an exam to earn a good grade, but that student would probably not seek out additional information on the topic once the exam is finished (Niemiec \& Ryan, 2009). The next type of extrinsic motivation is introjected 
regulation, whereby students begin to internalise the reasons for learning. However, this form of internalisation is not truly self-determined since it is driven by rewards and constraints that are imposed by the individual and not by others (Deci et al., 1991; Vallerand \& Bissonnette, 1992). For example, the student who originally studied to perform well on the exam now studies to feel pride or to avoid feeling guilty for not having studied enough. In this type of extrinsic motivation, ego involvement, which is refers to one's self esteem being contingent on one's performance, is internalised and accordingly a student feels internal pressure to learn so as to avoid shame or to feel worthy (Niemiec \& Ryan, 2009). Both external regulation and introjected regulation are perceived as having an external perceived locus of causality and negative learning effect (Guiffrida, 2006; Niemiec \& Ryan, 2009).

The next two types of extrinsic motivation with greater autonomy are identified regulation and integrated regulation. Identified regulation involves the motivation to engage in an activity because it is considered personally important or valuable. With identification, the regulatory process has become more fully a part of the self, so the person does the activity more willingly and autonomous. For instance, a student may study anatomy and physiology because mastery of such information is important for future competence in medicine (Deci et al., 1991; Niemiec \& Ryan, 2009; Ryan \& Deci, 2000a, 2000b; Sungur \& Senler, 2010). Finally, the most autonomous form of extrinsic motivation is integrated regulation. Integrated regulation involves both identification of the importance of behaviours and its integration to other aspects of self (Sungur \& Senler, 2010). For example, a student may plan to attend college since attending college can be in harmony with other aspects of the self. Both identified regulation and integrated regulation are perceived as emanating from, and congruent with, the self and thus have an internal perceived locus of causality (Niemiec \& Ryan, 2009; Sungur \& Senler, 2010). Integrated regulation has some relationship with intrinsic motivation because both are forms of autonomous self-regulation. However, intrinsic motivation and integrated regulation are different. Intrinsic motivation is characterised by interest in the activity itself, whereas integrated regulation is characterised by the activity's being personally important for a valued outcome (Deci et al., 1991).

\section{METHODOLOGY}

This study employed a mixed methods research, which focused on collecting, analysing, and integrating both quantitative and qualitative data in a single study (Creswell \& Clark, 2011; HesseBiber, 2010). According to Creswell and Clark (2011, p.5), the definition of a mixed methods research includes the following several characteristics that the researchers should do:

- Collect and analyse persuasively and rigorously both qualitative and quantitative data (based on research questions);

- Mix (or integrate or link) the two forms of data concurrently by combining them (or merging them), sequentially by having one build on the other, or embedding one within the other;

- Give priority to one or to both forms of data (in terms of what the research emphasises);

- Use these procedures in a single study or in multiple phases of a programme of study

- Frame these procedures within philosophical worldviews and theoretical lens; and

- Combine the procedures into specific research designs that direct the plan for conducting the study.

In terms of a mixed methods design, this study used the explanatory sequential design in two distinct interactive phases (Creswell \& Clark, 2011). This design started with the collection and analysis of quantitative data, which has the priority of explaining the relationship between student support and student persistence in the Indonesia Open University. In this first phase, the quantitative data were collected by using a web-survey. The population of this study was the undergraduate students of Faculty of Sosial and Political Sciences who enrolled from admission period of 2009/2010 to 2011/2012. The total number of 6,095 students were invited by email to participate in the web-survey. However, out of 6,095 invited students, only 153 respondents completed the questionnaire.

In the second phase, a multiple case study was employed to collect qualitative data through individual semi-structured interviews to help explain deeper the relationship between student support and student persistence. In this qualitative phase, Purposeful sampling was employed in this case study design by drawing samples from volunteered participants through the quantitative survey. There were 
69 participants who volunteered to participate in the interview by providing their email addresses and phone numbers. Considering a representation of diverse cases, a sampling strategy of maximum variation was used to represent enrolment status and gender across the cases (Creswell, 2007). However, of 69 participants who had been contacted through email and telephone, only 13 participants volunteered to participate in the interviews.

\section{FINDINGS}

\subsection{Quantitative Results}

The most typical age of participants was between 25 and 29 and the majority of them were men. Moreover, their ethnicity was predominantly identified as Javanese; they were mostly graduated from Senior High School; they were employed full-time; and they were primarily married and had children under 18.

The majority of participants undertook the course programme of English for Translation, followed then by Government Science. They were predominantly registered in the regional office of Jakarta and were identified as the active students. Furthermore, the most cited reason of non-enrolment for at least one registration period or more was workloads.

Meanwhile, frequency analysis of self-motivation scale including two scales: intrinsic motivation (four items) and extrinsic motivation (three items).

\subsubsection{Intrinsic motivation}

Intrinsic motivation scale consisted of four items and the results of the research indicated that the majority of participants from both active and inactive student groups had positive responses to all items. Furthermore, the median scores of data for both active and inactive student group were 4.0. These findings indicated that both active and inactive student group had high intrinsic motivation to study at the university.

In terms of Likert item analysis, the majority of active students had positive responses to learning new things in the University. They agreed (49.6\%) and strongly agreed (47.8\%) that they experienced pleasure and satisfaction while learning new things. Likewise, $92.8 \%$ of active students and $95.7 \%$ of inactive students responded positively that studying at the university would encourage them to learn about many things that interest them. At the same time, more than half of the active and inactive students $(73 \%)$ considered positively that studying at the university helped them to communicate their ideas to other people. Finally, more than $93 \%$ of the participants across the groups provided positive responses that they would get self-satisfaction if they could complete their Bachelor degrees within eight semesters.

For the first item, $47.8 \%$ of the participants in the active student group strongly agreed and $49.6 \%$ of participants agreed with the item "I experience pleasure and satisfaction while learning new things". $2.6 \%$ of participants remained unsure about their feelings. Meanwhile, in the inactive student group, $34.8 \%$ of participants strongly agreed with the statement and $60 \%$ of participants agreed with the statement.

Similarly, responses to the second item (Study at the University allows me to continue to learn about many things that interesting for me) were consistent with the first item. In the active student group, $49.6 \%$ of participants strongly agreed with the statement, $45.2 \%$ participants agreed with the statement, and $5.2 \%$ of participants neither agreed nor disagreed with the statement (in the 'unsure' option). On the other hand, in the inactive student group, $52.2 \%$ of participants strongly agreed with the statement and $40 \%$ of participants agreed with the statement. In addition, only $4.3 \%$ of participants selected the option of unsure.

In the third item (study at the University allows me to communicate my own ideas to others, particularly to my classmates), the responses were slightly different from the other questions. There were negative responses from the active and inactive groups. In the active student group, $18.0 \%$ of participants strongly agreed with the statement, $55.0 \%$ of participants agreed with the statement, $21.6 \%$ of participants were unsure with the statement, and $5.4 \%$ of participants disagreed with the statement. Meanwhile, in the inactive student group, $31.8 \%$ of participants strongly agreed with the statement, $54.5 \%$ of participants agreed with the statement, $9.1 \%$ of participants were unsure with the statement, and $4.5 \%$ of participants disagreed with the statement. 
The last item in the scale asked about self-satisfaction when completing the study within eight semesters (Study at the University allows me to experience a personal satisfaction with my quest for completing my study within eight semesters). There were no negative responses from the active and inactive student groups. Meanwhile, $52.7 \%$ of participants strongly agreed with the statement, $42.0 \%$ of participants stated that they agreed with the statement, $3.6 \%$ of participants were unsure, and $1.8 \%$ of participants disagreed with the statement. In addition, $34.8 \%$ of participants in the inactive student group strongly agreed with the statement, $43.5 \%$ of participants agreed with the statement, $17.4 \%$ of participants were unsure, and $4.3 \%$ of participants disagreed with the statement.

\subsubsection{Extrinsic motivation}

Extrinsic motivation scale had three items measuring external motivation to go to University. The results of the study delineated that the median scores of extrinsic motivation scale were 4.0 for both active and inactive student groups. These results indicated that the majority of active and inactive students had high extrinsic motivation to study at the Indonesian Open University.

The first item emphasises the extrinsic motivation to obtain a more respectable career in the future by studying at the University (I think that the University level of education will help me better prepare for a career that I have chosen). In the active student group, the majority of participants, $54.9 \%$, strongly agreed with the statement and $36.3 \%$ of participants agreed with the statement. Meanwhile, $6.2 \%$ of participants were unsure about the statement and $0.9 \%$ of participants disagreed with the statement. In the inactive student group, $59.1 \%$ of participants strongly agreed with the statement, $36.4 \%$ of participants agreed with the statement, and $4.5 \%$ of participants disagreed with the statement.

For the second item (in order to have a better salary later on), there were negative responses from the active group and the inactive group. In the active student group, $21.1 \%$ of participants strongly agreed with the statement, $44.3 \%$ of participants agreed with the statement, $17.4 \%$ of participants were unsure with the statement, $11.0 \%$ of participants disagreed with the statement, and $6.4 \%$ of participants strongly disagreed with the statement. Meanwhile, in the inactive group, $28.6 \%$ of participants strongly agreed with the statement, $47.6 \%$ of participants agreed with the statement, $19 \%$ of participants disagreed, and $4.8 \%$ of participants disagreed with the statement.

The last item on the scale reported on extrinsic motivation to attain social prestige in the community. The response to this item was slightly similar to prior item (extrinsic motivation to have a better salary later on). There were negative response from the active group and the inactive group. In the active group, $29.1 \%$ of participants strongly agreed with the statement, $45.5 \%$ of participants agreed with the statement, $11.8 \%$ of participants who unsure with the statement, $9.1 \%$ of participants disagreed with the statement, and $4.5 \%$ of participants strongly disagreed with the statement. In the inactive group, $30.8 \%$ of participants strongly agreed with the statement, $38.5 \%$ of participants agreed with the statement, $15.4 \%$ of participants were unsure with the statement, and $15.4 \%$ of participants disagreed with the statement.

\subsection{Qualitative Findings}

All the participants talked about intrinsic and extrinsic motivation related to their studies at the Indonesia Open University. Eight participants were primarily extrinsically motivated to get a better career after completing their studies. The career improvement was the dominant type of extrinsic motivation aside from the other two types: social prestige and helping other people. Meanwhile, five participants studying at the Indonesia Open University were driven by intrinsic motivation to increase their knowledge or learn new things from the University. Both these intrinsic and extrinsic motivations co-existed together in influencing participants' decisions in studying at the Indonesia Open University.

\subsubsection{Intrinsic motivation}

Five out of ten participants from the active student group (Wati, Ina, Hasan, Zulki, and Rama) stated that the main source of their motivation was to learn new things or knowledge in the University. For Wati, study at the university was her future goal since she was at the Senior High School. However, she had to disregard her ambition because her parents could not afford the tuition fee of the university, but this matter did not turn stop her motivation to study at the University because she always was fascinated to learn new knowledge:

....actually I really wanted to study at the University after graduated from Senior High School...but my parents did not have enough money to send me to university, although at that time I had been offered to study at a state university in the Bandung city. However, whatever would be, I still wanted to study at the university, to learn, and to get new knowledge (Wati). 
Ina, a student of the English Translation Programme, recounted another story. Initially, Ina took the management course programme at the Faculty of Economics in order to get a better job after completing the study. However, Ina was unhappy studying management, so she changed her course programme to English as this was a subject she interested in and rather than focusing on subject specifically for her future career. She only desired to study English translation skills and she was glad to learn such knowledge.

...I took a course programme that I liked. Therefore, I was just happy to do it and I did not think people would need it or not. I was basically happy and I wanted to explore deeply about English translation techniques...so it was not related to the future job. I had been studying just for my happiness (Ina).

Fascination to learn new knowledge was also a source of motivation for Hasan and Zulki. For Hasan, his involvement with political party development and political activities in Aceh made him interested in learning more about governance issues. Hasan decided to study governance issues and theories in the Indonesia Open University due to its flexibility for an employed person. Similarly, Zulki talked about his motivation to study at the university. Zulki was an English teacher at the Senior High School at Pangkalan Brandan, Medan. Zulki was already familiar with the Indonesia Open University since 2003 when he took a Diploma Course Programme in English Translation. In 2007, Zulki undertook the Bachelor degree in English Teaching and completed the programme in 2009. Zulki was always interested in acquiring new knowledge. When Indonesia Open University launched the Bachelor Degree of English Translation Programme in 2010, Zulki eagerly registered the course programme. Zulki said:

...I joined and studied at the Indonesia Open University because I liked to explore new knowledge...my motivation to keep learning made me always enrolled as an active student from the first commencement. Because I was used to learn, I felt like something was missing if I suspended my study at the Indonesia Open University (Zulki).

Meanwhile, for Rama his motivation to study at the university was to increase knowledge for better life in the future.

For these four participants, fascination to acquire new knowledge was the source of their intrinsic motivation to study at the Indonesia Open University. However, they admitted that being successful in their studies might help them to get a better job or career in the future. As Ina said: "...sometimes my friends asked me to help them to translate their documents...so perhaps I would create an English translation agency in the future...". Hasan also narrated: "...I could not deny that I had an interest to have a better career in the future, for example as a government employee".

Meanwhile, the participants from the non-active student group (Devi, Armi, and Dani) did not talk about intrinsic motivation. At the outset, all of them were extrinsically motivated to study in the Indonesia Open University for promoting their career and social prestige.

\section{Extrinsic Motivation}

Five participants from an active student group described that their pursuit of the Bachelor degree were extrinsically motivated to promote their career after completing their studies. Wawan was an active student since 2010 at the Faculty of Social and Political Sciences with the subject area of State Administration Science. He had been working as a treasurer at the Public Order Agency office in Tegal regency, Centre of Java. As a government employee, Wawan realised that the level of education was an important instrument for career progression.

My main motivation to go to University was to develop my career. Because just having Secondary Degree, my maximum level in the career that I could reach was III/B level. Meanwhile, if I had a Bachelor degree, I would be able to get III/D level, even without holding structural position and I wish could retire from the job in the level of IV/A (Wawan). 
In line with Wawan, Haril also indicated that his main motivation to go to university was to enhance his career. They each realised that the academic degree level would help them to improve their career prospects in the workplace.

...My main goal to study at the Indonesia Open University was for career improvement, so that if I could get a Bachelor degree, then at least I would get a higher level of career. It could not be denied (Haril).

Danu, Indra, and Santoso talked also about their sources of motivation for studying at the Indonesia Open University. For Danu, a government employee at the Bangka Regency, Bangka Province, his motivation to earn the Bachelor degree was related to his career. In Indra's case, his decision to study communication science at the Indonesia Open University was motivated to support his job as a volunteer in the community organisation. He also expected to get a better career in the future after earning the Bachelor degree. Meanwhile, for Santoso, he decided to study at the Indonesia Open University due to its flexibility for an employed student. Santoso had been working as an administrative staff at the private company and studied state administrative science at the Faculty of Social and Political Sciences. He realised that his course programme was not quite relevant to his current job because his future goal was to apply a job at the government office after earning the Bachelor degree.

...now I am 32 years old and I have to earn the Bachelor degree as soon as possible. I have a plan to apply for civil service job at the local government and it is required to have age under 35 years old (Santoso).

Meanwhile, for the non-active student group, all three participants had different sources of extrinsic motivation. For Fahri, an administrative staff at the primary school, studying at the Indonesia Open University was related to the school principal's request to manage the school library. His school principal suggested taking a course programme which could provide him library management skills. Fahri, though, suspended his study due to having a financial problem. For Amri, he was initially motivated to study at the Indonesia Open University in order to acquire a better career. However, when Amri later discovered that his Head Office did not recognise his selected course programme, he lost his motivation to continue his study. Meanwhile, for Devi, her motivation to study at the Indonesia Open University in order to earn the undergraduate degree for getting social prestige within her community groups. Her extrinsic motivation was different from the other participants who had job positions as staff and for Devi, as the owner of a business company, the university degree was not for improving her career prospects but rather for achieving social prestige within the community.

\section{LESSON LEARNED}

Self-motivation in this study was classified into two types of motivation: intrinsic and extrinsic motivation. The quantitative findings demonstrated that intrinsic and extrinsic motivation had positive effects on student persistence. Moreover, the qualitative multiple case study analysis indicated that intrinsic and extrinsic motivation did not stand in conflict and co-existed together in affecting student progress.

The co-existence between both types of motivation was probably driven by similar qualities shared between intrinsic and extrinsic motivation. The qualitative multiple case study found two major reasons why the participants were still motivated to continue their studies by re-enrolling within four consecutive semesters: 1) to learn new things; and 2) to get better career prospects. By referring to self-determination theory (SDT), "to learn new things" was classified into intrinsic motivation due to being enjoyable or satisfying in itself while learning something new. Meanwhile, "to get better career prospects" signified the participants' acceptance of the value of university degree for promoting their future career and thus represented the autonomous form of extrinsic motivation. In this sense, the participants represented an internal perceived locus of causality and integration of the value of learning activities into other values and needs (fully assimilated to the self). Although this extrinsic motivation shares many qualities with intrinsic motivation, it is still considered extrinsic due to being conducted for separable outcomes (rewards) rather than for inherent enjoyment (Ryan \& Deci, 2000b; Vansteenkiste, Lens, \& Deci, 2006). 
The findings in this study reinforced the idea that motivation was bounded with the learner and learning contexts. In the Open University contexts, intrinsic and extrinsic motivation strengthened each other and the autonomous types of extrinsic motivation had important roles in affecting student persistence. These findings supported the view that motivation is multidimensional and situational. In the online learning context, Hartnett, et al. (2011) found that students can be motivated for several different reasons and in different ways, often influenced by situational factors.

In line with these findings, another prior study conducted by Wilkesman, et al. (2012) also found that intrinsic and extrinsic motivation were the dominant predictors in deciding to and continuing with a university study for non-traditional students at three German Universities (TU Dortmund University, University Duisburg-Essen, and University of Oldenburg). The research also revealed that intrinsic and extrinsic aspects of academic motivation amplified each other. Therefore, additional selective incentives for intrinsically motivated students would not eliminate their intrinsic motivation.

\section{CONCLUSION}

The quantitative and qualitative findings revealed that self-motivation had a significance influence on student persistence at the Indonesia Open University. Furthermore, there were two types of motivation identified in the multiple case study analysis: intrinsic motivation as to learn new things and extrinsic motivation as to get better career prospects. These two sorts of motivation co-existed together in determining student persistence in the Indonesia Open University.

Intrinsic and extrinsic motivation had paramount effects on student persistence in the Indonesia Open University. The findings of this study also pointed out that intrinsic and extrinsic motivation amplify each other in influencing student persistence. Therefore, both intrinsic and extrinsic motivations should be supported and encouraged by developing the high standard of student supports, and effective and productive course design. This course design should include interactive and interesting learning design, effective learning materials, and productive communication. Interactive and interesting learning design may be implemented by applying several learning activities, such as problem-based learning, team-based learning, and others. Effective learning materials are developed by considering students' needs. Meanwhile, productive communication is designed to facilitate student-student interaction and student-institution interaction (Lee \& Choi, 2011).

\section{REFERENCES}

Belawati, T. (1998). Increasing Student Persistence in Indonesian Post-Secondary Distance Education. Distance Education, 19(1), 81-108. Journal Article.

Carr, S. (2000). As distance education comes of age, the challenge Is keeping the students. Chronicle of Higher Education, 46(23), A39.

Castles, J. (2004). Persistence and the Adult Learner: Factors Affecting Persistence in Open University Students. Active Learning in Higher Education. http://doi.org/10.1177/1469787404043813

Chen, K.-C., \& Jang, S.-J. (2010). Motivation in online learning: Testing a model of self-determination theory. Computers in Human Behavior, 26(4), 741-752. Journal Article. http://doi.org/10.1016/j.chb.2010.01.011

Chyung, S. Y. (Yonnie). (2001). Systematic and systemic approaches to reducing attrition rates in online higher education. American Journal of Distance Education, 15(3), 36-49. Journal Article. Retrieved from http://search.proquest.com/professional/docview/62285321 ? accountid=13963

Creswell, J. P., \& Clark, V. L. P. (2011). Designing and conducting mixed methods research (Second). Book, California: Sage Publications.

Creswell, J. W. (2007). Qualitative inquiry and reseach design: Choosing among five approaches. Book, California: Sage Publications.

Deci, E. L., Vallerand, R. J., Pelletier, L. G., \& Ryan, R. M. (1991). Motivation and education: The selfdetermination perspective. Educational Psychologist, 26(3 \& 4), 325-346. Journal Article. 
Diaz, D., \& Cartnal, R. (2006). Term Length as an Indicator of Attrition in Online Learning. Innovate: Journal of Online Education, 2(5). Electronic Article. Retrieved from http://www.innovateonline.info/index.php?view=article\&id=196

Guifrida, D. A. (2006). Toward a Cultural Advancement of Tinto's Theory. The Review of Higher Education, 29(4), 451-472. Journal Article. http://doi.org/10.1353/rhe.2006.0031

Hartnett, M., St. George, A., \& Dron, J. (2011). Examining motivation in online distance learning environments: Complex, multifaceted, and situation-dependent. The International Review of Research in Open and Distance Learning, 12(6).

Hesse-Biber, S. N. (2010). Mixed methods research: merging theory with practice. New York: The Guilford Press.

Ivankova, N. V, \& Stick, S. L. (2007). Students' Persistence in a Distributed Doctoral Program in Educational Leadership in Higher Education: A Mixed Methods Study. Research in Higher Education, 48(1), 93-135. Journal Article. http://doi.org/10.1007/s11162-006-9025-4

Kadarko, W. (2003). Kemampuan belajar mandiri dan faktor-faktor psikososial yang mempengaruhinya: Kasus Universitas Terbuka. Jurnal Pendidikan Terbuka Dan Jarak Jauh, 1(1). Journal Article.

Lee, Y., \& Choi, J. (2011). A review of online course dropout research: implications for practice and future research. Etr\&D-Educational Technology Research and Development, 59(5), 593-618. Journal Article. http://doi.org/10.1007/s11423-010-9177-y

Lee, Y., \& Choi, J. (2012). A structural equation model of predictors of online learning retention. The Internet and Higher Education, (0). http://doi.org/10.1016/j.iheduc.2012.01.005

Niemiec, C. P., \& Ryan, R. M. (2009). Autonomy, competence, and relatedness in the classroom: Applying self-determination theory to educational practice. Theory and Research in Education, 7(2), 133-144. Journal Article. http://doi.org/10.1177/1477878509104318

Osborn, V. (2001). Identifying At-Risk Students in Videoconferencing and Web-Based Distance Education. American Journal of Distance Education, 15(1), 41-54. Journal Article. Retrieved from http://search.proquest.com/professional/docview/62279034?accountid=13963

Parker, A. (1999). A Study of Variables that Predict Dropout from Distance Education. International Journal of Educational Technology, 1(2), 1-10. http://doi.org/Proquest:62307270

Parker, A. (2003). Identifyfing predictors of academic persistence in distance education. United States Distance Learning Association Journal, 17(1), 55-62.

Poellhuber, B., Chomienne, M., \& Karsenti, T. (2008). The Effect of Peer Collaboration and Collaborative Learning on Self-Efficacy and Persistence in a Learner-Paced Continuous Intake Model. Journal of Distance Education, 22(3), 41-62. Journal Article. Retrieved from http://search.proquest.com/professional/docview/61798157?accountid=13963

Ratnaningsih et.al., D. J. (2008). Analisis daya tahan mahasiswa putus kuliah pada pendidikan tinggi jarak jauh: Studi kasus mahasiswa Jurusan Manajemen Fakultas Ekonomi Universitas Terbuka. Jurnal Pendidikan Terbuka Dan Jarak Jauh, 9(2), 101-110. Journal Article.

Rotter, J. (1966). Generalized expectations for internal versus external control reinforcement. Psychological Monograph, 80(1), 1-28.

Ryan, R. M., \& Deci, E. L. (2000a). Intrinsic and Extrinsic Motivations: Classic Definitions and New Directions. Contemporary Educational Psychology, 25(1), 54-67. Journal Article. http://doi.org/10.1006/ceps.1999.1020

Ryan, R. M., \& Deci, E. L. (2000b). Self-determination theory and the facilitation of intrinsic motivation, social development, and well-being. The American Psychologist, 55(1), 68-78.

Simpson, O. (2003). Student retention in online, open, and distance learning (1st ed.). London: Kogan Page.

Simpson, O. (2008). Motivating learners in open and distance learning: do we need a new theory of learner support? Open Learning: The Journal of Open, Distance and E-Learning, 23(3), 159170. Journal Article. http://doi.org/10.1080/02680510802419979 
Sungur, S., \& Senler, B. (2010). Students' achievement goals in relation to academic motivation, competence expectancy, and classroom environment perceptions. Educational Research and Evaluation, 14(4), 303-324. Journal Article.

Universitas Terbuka. (2012). UT dalam angka pada 30 April 2012 [Online Database]. Retrieved from http://www.ut.ac.id/tentang-ut/ut-dalam-angka.html\#kepulauan

Universitas Terbuka. (2016). UT dalam Angka 2016.1.

Vallerand, R. J., \& Bissonnette, R. (1992). Intrinsic, extrinsic, and amotivational styles as predictors of behavior: A prospective study. Journal of Personality, 60(3). Journal Article.

Vallerand, R. J., Pelletier, L. G., Blais, M. R., Hriere, N. M., Senecal, C., \& Valleries, E. F. (1992). The academic motivation scale: A measure of intrinsic, extrinsic, and amotivation in education. Educational and Psychological Measurement, 52, 1003-1017. Journal Article.

Vansteenkiste, M., Lens, W., \& Deci, E. L. (2006). Intrinsic Versus Extrinsic Goal Contents in SelfDetermination Theory: Another Look at the Quality of Academic Motivation. Educational Psychologist.

Wilkesman, U., Fischer, H., \& Virgillito, A. (2012). Academic motivation of students: The German case (ISSN 1863-0294). Dortmund, Germany. 